\title{
Public Private Partnerships and Public Procurement
}

\section{Darrin Grimsey and Mervyn Lewis}

$\mathrm{P}$ ublic Private Partnerships (PPPs) rarely get good press, and public opinion is quick to condemn a PPP that does not succeed as a failure of the concept itself. Perhaps it is because, as Tony Harris, one of the staunchest critics of PPPs, once observed '... good news stories receive little attention in public ... . The private infrastructure projects which appear less credible ... get rather more attention' (Harris, 1998:11). His successor as NSW Auditor-General, Bob Sendt, admitted that 'the public - and possibly the political - mood has certainly turned against PPPs as a result of the Cross City Tunnel' (Sendt, 2006:3).

While many in the community may remain suspicious of private sector involvement in public infrastructure, the reality is that old 'command and control' structures in the public sector are breaking down and are being replaced by new interrelationships between government and private sector entities. Rather than as an aberration, PPPs (or perhaps more correctly 'traditional' PPPs) need to be viewed as one form of public procurement, supported by many hybrid approaches that blur the lines between them and conventional procurement methods.

This article examines this evolving marketplace. It begins by comparing conventional forms of public procurement with traditional PPPs, and then reviews the relative performance, and advantages and disadvantages, of these alternatives. PPPs are argued to introduce very different incentive structures and responsibilities into the procurement process. Nevertheless, traditional PPP models have some well-recognised limitations. Against this background, the article considers these problems and the new hybrids of PPPs and traditional procurement that have been developed, and experimented with, to address these issues. Consequently, there are no hard and fast rules as to what situations work best for PPPs. The real question is what particular procurement option, which may or may not be a PPP variant, is appropriate for the project on hand.

\section{Forms of Procurement}

With traditional procurement private companies have long been involved in building roads, hospitals, schools and public buildings, and in providing management and maintenance services. What differs with a PPP is that these separate arrangements are combined (bundled) into one contract and a private sector entity charged with providing, not a building, but a flow of infrastructure services over time.

For example, under conventional procurement, the public sector body may enter first into a Design-Build (DB) contract, engaging a private sector firm to design and build a facility in accordance with requirements determined by the

Darrin Grimsey is Partner, Ernst \& Young, Project Finance Advisory, Melbourne, and Mervyn Lewis is Professor of Banking and Finance, University of South Australia. 
government. After the facility is completed and paid for, the government assumes responsibility for operating and maintaining the facility. It may then use a service or management contract to outsource all or part of operations and maintenance.

With a PPP, these separate contracts would be combined. For example, with a Design-Build-Finance-Operate-Maintain (DBFOM) contract the private sector entity, usually a Special Purpose Vehicle (SPV) company created for the project, designs, builds, finances, operates and maintains a new or refurbished facility under a long-term lease $(20,30$ years or more). At the end of the concession period, the private party transfers the facility to the public sector. This is only one example. There is a multitude of acronyms, covering a variety of transactions allocating to the private sector a right to operate traditional public sector services.

An obvious question is why a government body would engage in a DBFOM transaction. Why would it tie its hands in this way for 20-30 years, say, rather than opt for the flexibility of separate contracts? The question is heightened when it is appreciated that the SPV will itself enter into a separate contract for design or design-build with a construction company, a financing arrangement with senior lenders, and an operations and maintenance contract with a facilities management company. Why is it presumed that the SPV company can contract more cheaply or effectively with the other parties than can the government body?

One answer is that the arrangement does appear to work, at least in many cases, and we will provide some evidence on this point later. In our view the difference lies in different levels of responsibility and accountability. In conventional procurement, when the government acquires the infrastructure, designs the facility and delivers the service, it does so in an environment largely removed from the economic signals to which private entities are exposed. The government's cost of fund raising, whether by debt or taxation or charges, bears no relationship to the project's risks or its likely success or failure. A wide variety of performance outcomes can be swept under the administrative mat, and the principals involved are often insulated from the consequences of their actions and decisions. Infrastructure decisions necessarily have consequences and generate obligations that last for generations. Yet the politicians and senior officials making them bear little personal responsibility for the consequences, and thus face few incentives to modify or change their behaviour (Stone, 2006).

By contrast, a well structured PPP can introduce clear lines of accountability, transparency of outcomes and performance, clarity as to the roles and responsibilities of the contracting parties, an assessment of the project risks, competition for the delivery of services, and the motivation to succeed. Table 1 compares the characteristics, and thus the advantages and disadvantages of two forms of conventional procurement (fixed price, managing contractor) with a traditional PPP of the DBFOM or DBFM type. Some comments follow.

\section{Fixed price}

Under a Fixed Price contract, the government separately engages a design team to develop the design component of the documentation used to tender the construction contract. The successful contractor has to deliver the works at the fixed price tendered provided there are no variations to the design. In practice, such contracts are rarely delivered to the tendered price. Often the public sector 
body varies its design either due to changes in scope or in response to risks that the government retains under this form of contract, such as latent conditions, and delays caused by the public sector entities.

\section{Table 1: Comparing Traditional and PPP Procurement Models}

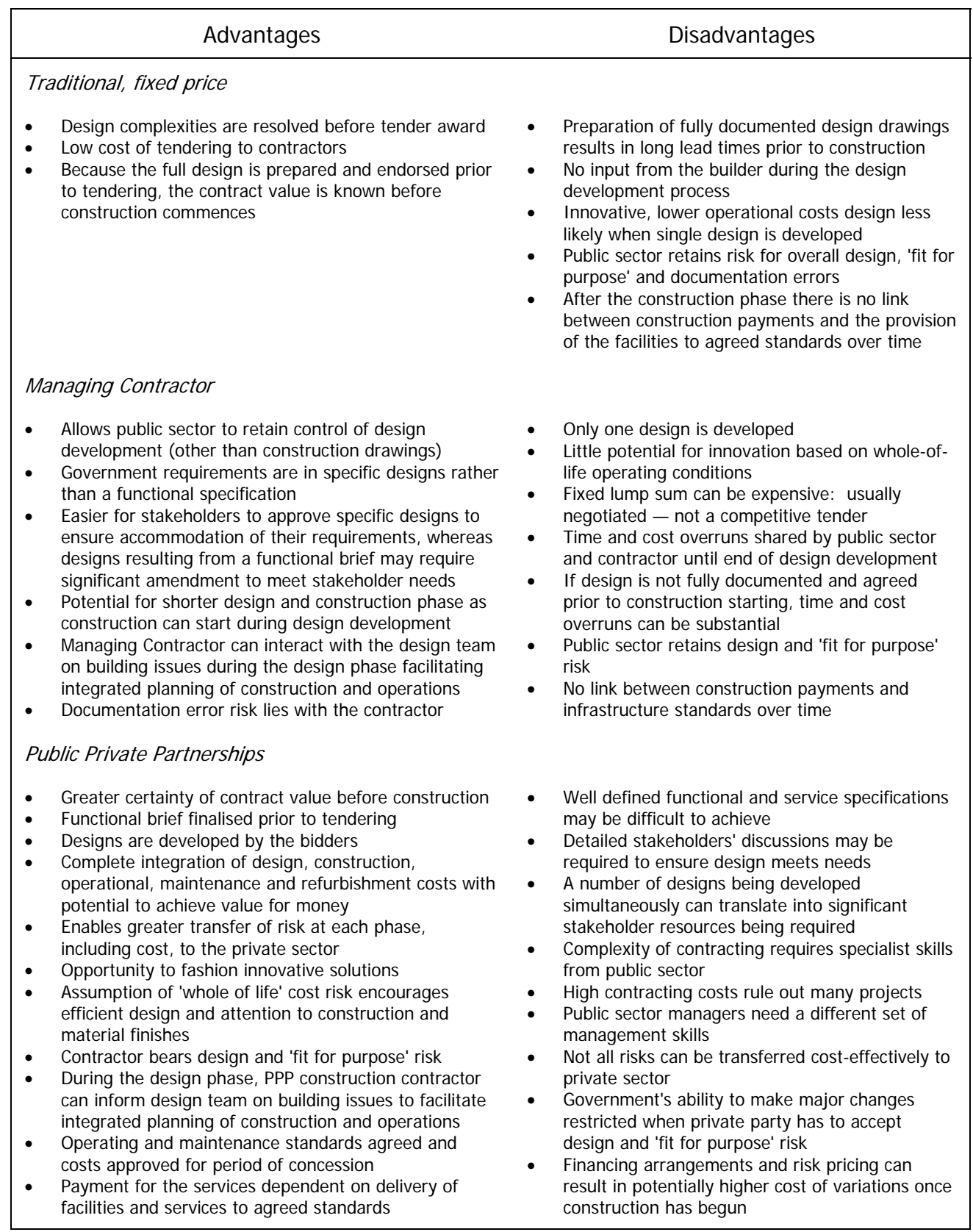

Source: Based on Ernst \& Young Project Finance Advisory. 


\section{Managing contractor}

Under a Managing Contractor arrangement, the public sector engages a contractor to manage some or all aspects of the design, documentation and build phases of a project on behalf of the government for an agreed lump sum (consisting of the management fee and the cost of the work done under the component sub-contracts). The benefits of this type of contract are its flexibility and the skills which the managing contractor may be able to apply to procuring of the works and to the preparation of the documentation and trade packages.

$P P P$

Under a PPP, the government instead becomes a purchaser of asset-based infrastructure services that are paid for against performance. There is potential for the PPP to deliver value for money where:

- it is possible to clearly define required outputs to allow a payment mechanism to be structured that aligns with project objectives;

- $\quad$ the project has scope for innovation;

- there are opportunities for the transfer of certain risks (for example, design, cost and time overruns) to the private sector that it can better manage;

- whole-of-life costing can reduce operating costs by building in features that a focus on immediate construction costs would ignore;

- reliance on user fees for revenue can create an incentive for private operators to provide good customer service; and

- $\quad$ proper maintenance can lengthen the life of the facility and increase residual asset value.

\section{Relative Procurement Performance}

Are these expectations that PPPs have the potential to deliver value of money realised in practice? Ideally, the performance of PPPs would be assessed over the entire lifecycle of the project, from construction to operations to end of contract (Blanc-Brude, Goldsmith and Valila, 2006). However, with most projects either under construction or in their early stages of realisation, available evidence relates mainly to two things: construction outcomes and projected value-for-money.

\section{Construction under traditional procurement}

One of the attractions of PPPs (especially to those in charge of allocating public sector resources) is their capacity to resolve the large cost overruns and delays in traditional public procurement ('optimism bias') that has been demonstrated in several studies:

- Hodgson (1995) notes that cost and time overruns under conventional procurements for UK roads are common.

- Mackie and Preston (1998) identify 21 sources of error and bias in UK transport projects. 
- A study by Flyvbjerg, Holm and Buhl (2002) of 258 large transport infrastructure projects over 20 countries found costs to be underestimated in 90 per cent of cases by an average of 39 per cent.

- $\quad$ The Mott MacDonald (2002) study of 39 large UK infrastructure projects procured by conventional means found that completion time exceeded estimated duration by 17 per cent, while capital expenditure costs exceeded estimates by 47 per cent on average.

- Flyvbjerg, Holm and Buhl (2005) in a study of 210 transport projects found rail passenger forecasts were over-estimated by an average of 106 per cent and that onehalf of road projects differ between actual and forecast traffic by more than 20 per cent.

- A report commissioned by HM Treasury in 2004 found that the outturn costs of conventional procurement projects were 2 to 24 per cent higher than the estimate in the business case (Leahy, 2005).

\section{PPP construction performance}

PPP's construction performance vis-à-vis traditional procurement was evaluated in several studies:

- $\quad$ Eleven of the 50 UK projects examined by Mott MacDonald (2002) were PPPs. On average they came in under-time (relative to 17 per cent over-time for conventional procurement), while capital expenditure was on average 1 per cent over budget (relative to an average cost over-run of 47 per cent for traditional procurement).

- $\quad$ HM Treasury (2003) researched 61 PPP projects. Overall 89 per cent of projects were delivered on time or early, and all projects were within public sector budgets.

- The UK National Audit Office (NAO, 2003; 2005) compared the construction performance of PPP and traditional procurement. Only 30 per cent of conventional projects were on time and only 27 per cent were within budget. By contrast, the PPPs were largely delivered on time or early (76 per cent versus 30 per cent) and on budget ( 78 per cent versus 27 per cent).

- A European Investment Bank study (Thomson, 2005) made an in-depth evaluation of 10 PPP projects financed by the Bank. Only 3 out of the 10 PPP projects exhibited time delays and cost overruns, but the additional costs were borne by the promoter not by the public sector bodies. By contrast, of the 50 public infrastructure projects under conventional procurement, 60 per cent were more than one year late.

\section{Value-for-money tests}

The figures above relate to construction cost and time overruns. Value for money (VFM) tests based on comparisons of the PPP application with the benchmark cost of providing the specified service using conventional public procurement methods (the Public Sector Comparator or PSC) enable us to put some numbers on the expected overall gains from PPPs.

- An early NAO (1998) study of the first four DBFO (design-build-finance-operate) road contracts found that they were likely to generate net quantifiable financial savings of around 100 million pounds (13 per cent).

- A study by LSE/Arthur Andersen (Arthur Andersen, 2000) analysed 29 public sector projects that used the private finance initiative (PFI: the UK programme encompassing PPP) and calculated that on average the predicted savings from using the PFI, compared with conventional procurement, was 17 per cent. 
- $\quad$ The UK National Audit Office (NAO, 2001) produced VFM reports on 15 projects, 7 of which were evaluated for VFM against a PSC. Overall, the total cost savings of these projects was 20 per cent.

- $\quad$ Parker and Hartley (2003) record claims that PPP contracts for UK defence services have resulted in cost savings between 5 per cent and 40 per cent compared with conventional public procurement, although the authors question whether these apparent cost savings will be realised due to uncertainties of long-term contracting.

- In Australia, a review in 2004 of the Partnerships Victoria policy found evidence of net benefits of PPPs, and that for the 8 PPP projects examined the weighted average savings was 9 per cent across all projects (Fitzgerald, 2004).

- In Germany, a pilot PPP programme has been underway in the Lander since 2004. A VFM test involving a PPP-PSC comparison is required to be applied in three steps: when selecting the project for PPP treatment; to assess possible VFM gains prior to tender; and after tender with data from the preferred bidder. For projects developed to date, PSC calculations were made, and VFM gains were achieved with all assessed projects varying from 1-25 per cent for VFM tests prior to tender to 6 to 15 per cent for the preferred bid (Sachs et al, 2005).

Finally, there are some individual case studies. In the Netherlands, the Wastewater Treatment Delfland PPP (Europe's largest water PPP), concluded in 2003, has an expected saving of around 15 per cent compared with the PSC. Grimsey and Lewis (2004c, 2005a) provide eight case studies of PPP projects in the US, Australia, UK and Pakistan covering waste water projects, two hospitals, two prisons, light rail and a road project. In three cases, no PSC calculation was made and value for money was sought by means of a competitive bidding process. In two cases, the VFM gains were trivial (less than one-half of one per cent) ${ }^{1}$. In the case of the other three projects, VFM gains ranged between 9 and 16 per cent.

Why? How can we explain such findings? What aspects of a PPP are likely to influence performance? The next section seeks to provide some answers.

\section{Explaining Performance Differences}

It might be argued that PPPs are handpicked to succeed. Despite the attention given to, and concerns raised about, PPPs in the academic literature and in public discussion, they are a small part of the public infrastructure market. PPP/PFI accounts for between only 10-14 per cent of public sector investment in the UK and PPPs for about 10 per cent in Victoria, the leading market in Australia. Most public infrastructure projects are still traditionally procured. On these grounds it could be said that PPPs are the crème de la crème and thus more likely to be successful. However, this overlooks the resistance to PPPs, within much of the public administration and also, if true, begs the question of why any PPPs fail.

Economic theory suggests that the performance differences may lie in the characteristics of PPPs that differentiate them from conventional procurement. The economic literature on PPPs has identified three features of a PPP that may

\footnotetext{
${ }^{1}$ In one of these projects the lowest bidder was not chosen to widen the market for PPP contractors, while in the other case, the PPP was preferred on the basis of lower risk to the public purse.
} 
cause its productive efficiency to differ from traditional procurement: ownership, bundling and risk transfer (Blanc-Brude, Goldsmith and Valila, 2006).

\section{Ownership rights}

Blanc-Brude, Goldsmith and Valila (2006) argue that ownership rights are a good starting point for considering the economic consequences of PPPs, under incomplete contracting arrangements (Macniel, 1974; Grossman and Hart, 1986; Hart and Moore, 1990). Under a PPP, the public sector transfers land, property or facilities controlled by it to the private sector which is given ownership or control rights for the term of the concession or lease. This assignment of the residual control rights provides an incentive for the private sector entity to undertake relation-specific cost-saving investment (for example, in road maintenance technology) that increases productive efficiency. In the absence of this assignment the private firm would not be sure that the investment would pay off and there would be under-investment in the new technology. Turning over the control rights for the infrastructure can alleviate this problem.

\section{Bundling}

Another defining characteristic of a PPP is 'bundling', whereby the infrastructure asset's construction and operation is combined in a single contractual framework (Hart, 2003). Hart framed the issues in terms of transactions costs, with the choice between bundled or unbundled structures governed by whether it is easier to write contracts on service provision than on the quality of the building. The PPP is better if the quality of the service can be well specified in the original contract, whereas the quality of the building cannot; vice versa for 'unbundling'. In addition, however, bundling may be a way of altering incentives, by allowing for the internalisation of externalities between the construction and operation phases of the project (Blanc-Brude, Goldsmith and Valila, 2006). Bundling of construction and operations offers an incentive to make larger upfront outlays in the construction phase in order to achieve lower life-cycle maintenance costs. In the absence of bundling, these externalities would not be taken into account in construction and productive efficiency would be lower.

\section{Risk transfer}

The transfer of risk to the private sector can also make a PPP more cost efficient than traditional procurement. Grout (1997; 2003; 2005) emphasises information costs and the incentive structure created by the PPP service payment mechanism. Determining responsibility for cost overruns is a serious source of conflict when there are design changes or other unexpected developments. Writing the contract in terms of the flow of services from the infrastructure facility rather than the process of construction can change the incentive system. If, for example, the same entity is responsible for both construction and supplying the services, but is remunerated only for the successful provision of services of a suitable quality, the entity needs to build the correct facility, get the delivery process right, and contain 
costs while not sacrificing quality. These incentives are blunted under traditional procurement if the public sector carries most construction cost and delay risk.

Indeed, in all respects, an effective transfer of risk from the public to the private sector can lead to a more explicit treatment of risk, since it is the acceptance of risk that gives the private entity the motivation to price and produce efficiently. Private finance (debt and equity) is central to this process, although its role has been overlooked so far in the theoretical PPP literature. Having the privately-provided finance at risk acts as a catalyst for the injection of risk management techniques into the project in a way that is not possible under government financing. For the latter, the cost of capital is artificially low, because the public sector can transfer risks to taxpayers and end users without having to compensate them. This underpricing of risk in traditional procurement skews decision-making by removing it from the incentives to prevent cost overruns and project delays that would put revenue streams under threat.

These insights carry implications for the ex ante costs of constructing infrastructure under a PPP in comparison with traditional procurement. Asset construction costs should be higher under a PPP whenever there is scope for relation-specific, cost-saving investments to be made. Likewise, construction costs under bundled contracts will exceed those with unbundling if there is the potential to make additional outlays in the construction phase which lead to lifecycle cost-savings. Construction costs will also be higher under PPPs because of the explicit recognition, quantification and pricing of construction and other risks transferred to the private sector partner, who will want to be compensated for carrying them. In general terms, this would appear to be the case based on a study of European road projects, with the largest part of the estimated difference seemingly representing the cost of passing on construction risk to the private entity (Blanc-Brude, Goldsmith and Valila, 2006). In effect, it would seem that the public sector pays more for a PPP road ex ante primarily to avoid time and cost overruns. Since changes due to client requirements are the main cause of cost variations in both PPP and traditionally procured projects, 'one of the arguments for PPP is that the process of preparing output based specifications makes the public sector focus on exactly what it wants. Hence changes causing cost increases become less likely.' Besides, 'the incentive to present realistic construction budgets are weaker in traditional procurement, given weaker accountability in the event of cost overruns' (p. 32). Overall, the authors conclude that 'while it would thus seem that the transfer of the construction risk is successful in PPPs, one can nevertheless not conclude that it unambiguously creates "value for money" ', because 'the public sector could transfer construction risk in traditional public procurement by entering fixed-price, date-certain construction contracts' and 'making use of schemes to provide incentives' (p. 31). Some of these alternatives are considered below.

\section{Problems of PPPs}

Readers may object that we have offered a very selective account. What about the Cross City Tunnel fiasco, the difficulties of Spencer Street Station, controversies about PPPs in the UK National Health Service and the high cost of private finance (and financiers' fees) relative to government funding of projects? 
It is too early yet to know what impact the Sydney Cross City Tunnel will have on public finances. What can be said is that the two (east and west) $2.1 \mathrm{~km}$ 'long 80 ' tunnels exiting east of the Kings Cross Tunnel to the east and connecting to the Western Distributor in the west, along with a third ventilation tunnel, are an engineering triumph, delivered on time and on budget. Rather, the size of the upfront payment to the public purse (not an unusual payment: see Brown, 2005) and its implications for the tariff levied, along with the road closures to 'return William Street to the people' that were seen as putting cash into the developers' pockets, all undermined the legitimacy of the venture. The primary objectives of the project, to remove much east-west traffic from central Sydney streets, improve the environment of central Sydney streets, and reduce east-west travelling times, were thus compromised. ${ }^{2}$ In the words of the NSW AuditorGeneral, 'the focus became the tunnel itself, rather than the wider objectives' (Sendt, 2006:5).

Spencer Street Station in Melbourne (now Southern Cross Station) with its iconic roof is an architectural triumph, and also illustrates the potential for innovation that a PPP can bring. From the outset the winning bidder did not think of the project as a station, which is what might have happened under traditional procurement. Instead, Civic Nexus saw the location as a junction point where people congregate with cash in their pocket, and it set about combining transport, retail, commercial office space, and residential inner-city accommodation in a way that integrates the adjoining Docklands development and stadium into the City of Melbourne. Press reports (over 100 in one year alone) made much of access problems and delays encountered by the contractors. Yet the reality is that a world-class transport interchange has been completed, with office accommodation and shops, and nearly all of the $\$ 110$ million of construction losses are borne by the contractor and do not fall upon the taxpayers.

Elsewhere, the authors (Grimsey and Lewis, 2005b) have addressed some of the criticisms made of PPPs. In that article we focused on a number of issues: PPPs in the National Health Service, the role of the PSC and the PPP-PSC assessment, the discount rate used for PPP cashflows and the PPP-PSC comparison, the treatment of uncertainty in risk transfer, and the long-term evaluation of PPP projects within a governance framework (Grimsey and Lewis, 2004b). Here we examine some different issues.

\section{Some contentious issues}

Cost of finance. One of the perennial objections to PPPs is that the private sector's cost of funds is more expensive than the government's cost of debt used to fund a traditional procurement. This is true, but only up to a point, for the 'lower government borrowing cost' argument is also seriously flawed. What is important is the 'true' risk of the project. Private provision of finance, that is, the PPP route, explicitly builds this risk into the cost of funds, whereas the government's cost of borrowing does not. The relevant comparison needs to allow for risk and uncertainty (Grimsey and Lewis, 2004a).

${ }^{2}$ We thank Vikram Bhatia of the University of South Australia for his valuable research into this project. 
Excess returns. A study commissioned some years ago, and undertaken by PricewaterhouseCoopers (PwC) (2002), analysed the projected rates of return on a sample of $64 \mathrm{PFI}$ projects to ascertain whether the returns that the private sector expected to earn for managing and bearing risk were excessive or in line with what might be anticipated from a competitive market among bidders. We noted earlier that, on similar reasoning, construction costs on PPPs might be expected to be higher than for traditional procurement. The PwC study takes as its starting point the proposition that, with competition, project internal rates of return should reflect exactly the returns required by diversified investors, as indicated by the weighted average cost of capital. Across all projects in the sample, the real internal rate of return is found to average 7.7 per cent per annum. By comparison, the average weighted cost of capital is estimated using CAPM to be 5.3 per cent per annum. Thus the 'spread', the amount by which the average project internal rate of return is higher than the cost of capital, is 2.4 per cent per annum. Of this amount, 1.7 per cent is thought to be accounted for by two factors: unrecovered bid costs on other projects (about 1 per cent); and the higher cost of private sector borrowing compared with public sector borrowing (about 0.7 per cent). Consequently, the 'excess' project return to project investors is estimated as being at most about 0.7 per cent. We say 'at most' because some part of this margin, attributed in the report to 'structural issues' that have limited competition in the bid market, could be a margin built in for uncertainty, which is not allowed for in the analysis (Grimsey and Lewis, 2004c).

Nevertheless, in a number of well-publicised cases, debt has been refinanced, boosting the sponsors' rate of return (in one case from 12.8 to 39 per cent $\mathrm{pa}$, and in another from 19 to 60 per cent pa) and providing investment banks with large upfront fees. In one case concerned (Fazakerley PFI prison), the consortium was able to refinance the project because of its success in delivering the project ahead of time and establishing a track record of operations, lowering the perceived risk of PFI-backed debt. HM Prison Service argued the importance of not removing the opportunities for the private firms to benefit substantially from successful risk-taking. The solution that emerged was a cost-sharing formula to apply to such windfall gains in new contracts, although it remains an issue with existing contracts (House of Commons Committee of Public Accounts, 2006a). Revenue-sharing provisions are common for PPP road projects in Australia, with the public sector sharing in toll revenue in excess of base case forecasts (Brown, 2005).

Drag on government budgets. Payments under PPP schemes involve significant fixed payments to cover interest charges and capital repayment. These debt repayment charges introduced into the finances of public sector authorities are said to limit the later flexibility of these bodies, by 'mortgaging the future' in return for immediate gains since payments a transferred to the future. The counter-argument is that construction can be brought forward with the cost of infrastructure investment spread over the life of the asset, much as homebuyers do when they take out a mortgage or use leasing and hire purchase facilities. At another level, the contractually binding commitment over the project life for the services included in the project can be criticised for reducing the autonomy of 
public sector management in relation to discretionary spending. Concurrently, however, it removes the ability to divert funding from needed maintenance work.

Incomplete risk transfer. Critics often suggest that there is no substantive risk transfer under a PPP. However, this is truer of the traditional approach with design and construct. As the builder is not responsible for how the buildings function, there is an implicit temptation to build (or at least tender) cheaply. There is also not an incentive to take into account the whole of life trade-offs that might exist. Under a PPP approach the contractor is forced to think longer term and also cannot just 'walk away' having completed the construction. The contractor has ongoing, long-term responsibility for the facility's performance, which is reflected in performance-based monthly payments. Even if the contractor is unable to fulfil its obligations, and terminates the partnership, it cannot take the facility away and, in most cases, the assets revert to the public sector.

Access. Concerns are also expressed about community access and user fees charged for access, although these can be addressed in the contract to ensure that access rights are the same as other facilities and that user charges are limited to the rate of inflation or some other predetermined rate. Privately-owned and operated toll roads have been especially controversial in Australia. Some, such as Tony Harris (2006:1) are opposed to the very idea: 'in an urban environment toll roads are ridiculous and privately owned toll roads are even more ridiculous'. The objection is that the toll roads break up a complex network into segments with separate tolling creating additional transactions costs (Harris, 1998:6). Another objection raised is that 'direct tolling forces between 20 and 40 per cent of motorists off these low-cost infrastructure facilities on to more expensive stop-start arterial roads and therefore reduces the economic benefits of the facility' (Cox, 2005:8). These difficulties can be avoided by remunerating the contractor by shadow tolls based on availability and other performance indicators (such as surface conditions, lighting and verge conditions). But then other problems arise. Clarke and Hawkins (2006) criticise City Link and other urban road networks because the tolls are for cost-recovery and not efficiency-based, such as being higher at peak periods to reflect higher congestion costs. There are no easy answers to such matters. These issues are being played out also in the United States as roads, bridges and airports are being sold off to private interests such as Transurban and Macquarie Infrastructure Group (Thornton, 2007).

\section{Some other concerns}

Technological change. PPPs are said to require a degree of certainty about the type of infrastructure or services needed. A high degree of certainty is needed as to the desired output specification and infrastructure required. For this reason, the conventional wisdom is that information technology (IT) projects are subject to such uncertainties and complexities as to render them unsuitable for PPP delivery. Interestingly, however, the Glasgow Schools PFI Project, awarded in 2000, involving the construction of 12 new schools and modernisation of 17 schools, included an Information Communication Technology (ICT) network for all 29 schools incorporating scope for expansion and upgrades for technological change (Goldstone, 2001; Ernst \& Young, 2006). 
Inflexibility. PPP contracts contain detailed specification of the outputs required and the penalties for not meeting them under long-term contracts that are inflexible. If the government wishes to alter its service requirements, this is possible but may prove to be costly. While PPPs in particular have been criticised on this score, the reality is that inflexibility is present regardless of the procurement route. There are few things more irreversible than a building or piece of infrastructure. If flexibility and catering for changing needs is important, then these features need to be incorporated into what is being procured irrespective of the method of procurement. Indeed, PPPs might be said to have merits in these terms. First, the PPP model forces upfront consideration of what long term flexibility is likely to be required to respond to demographic and other changes. Boundaries for flexibility can then be specified and the risk of designing in and delivering on this flexibility can be transferred to the private sector under the PPP. Second, the costs of doing away with all or part of a PPP are accurately known whereas the costs of changing conventionally-procured facilities are hidden from view and are frequently under-costed because such long-run considerations are usually ignored.

Procurement costs. The average procurement time for PPP projects is around 22 months in the UK and 12-18 months in Australia. It takes a long time to agree the risk transfers, payments and terms that are acceptable to both parties - imposing considerable legal and due diligence costs on both the contractors and public sector side. The combination of time and due diligence means that multi-million dollar bid costs are at risk. Private parties will expect the contractual arrangements to cover the financial risks that they face. PPPs are generally not recommended for small individual projects, although combining a number of small projects helps to spread procurement costs across several projects. Overall procurement costs could be reduced if it were accepted that PPPs had been sufficiently 'road-tested' in certain applications, thereby dispensing with the (not inconsiderable) cost of preparing the PSC. A competitive bidding process would then ensure VFM. This is effectively what France has done with concessions for water and many other municipal services.

Wrapping a number of projects together is one of a number of developments that have occurred in recent years to lower procurement costs of traditional PPPs, introduce flexibility and allow for uncertainties and technological change. Because they often combine some elements of PPPs and conventional procurement we refer to them as hybrids.

\section{Hybrid Approaches}

Table 2 summarises the advantages and disadvantages of the hybrid models, which are also outlined below. All seek to retain the incentive structures and clear lines of responsibility that mark the PPP approach.

\section{LIFT/LEP}

The Local Improvement Finance Trusts (LIFT) and Local Education Partnership (LEP) can be seen as variants of a broadly similar approach to procurement, whereby contracting with a single partner for several small-sized projects on a 
staged basis reduces the costs of transacting and shortens the length of the procurement process. Both are based around the formation of joint venture (JV) companies in which the various public sector entities have a minority interest. The JV LIFTCo signs a 20-25 year undertaking to deliver partnering services in relation to the provision of local primary health needs, agreeing to develop a certain number of projects initially, others later, with funding staged. The programme was launched in the UK in 2000 . Under LEP the initial work is likely to be undertaken by the particular private partner to establish VFM benchmarks. Thereafter the public sector has the right to market test proposals. The first LEP (for Bristol) reached financial conclusion in J une 2006.

\section{Table 2: Comparison of Hybrid Models}

\begin{tabular}{|c|c|}
\hline Advantages & Disadvantages \\
\hline $\begin{array}{l}\text { LIFT/LEP } \\
\text { - } \quad \text { Potential for lower procurement costs over project } \\
\text { life } \\
\text { - } \quad \text { Allows for flexibility over programme delivery } \\
\text { - } \quad \text { comables the public sector to maintain influence over } \\
\text { - } \quad \text { private sector partner } \\
\text { Builds in scope for continuous improvement } \\
\text { throughout successive phases of work }\end{array}$ & $\begin{array}{l}\text { - } \quad \text { Scope for conflict of interest for strategic partner } \\
\text { - } \quad \text { VFM relies on benchmarking of early work } \\
\text { - } \quad \text { Reluctance for public sector to utilise alternative } \\
\text { providers }\end{array}$ \\
\hline $\begin{array}{l}\text { MoDEL (Prime Plus Contractor) } \\
\text { - } \quad \text { Enables lower procurement costs over project life } \\
\text { - } \quad \text { Gives flexibility over programme delivery } \\
\text { Public sector can retain influence over strategic } \\
\text { direction of investment } \\
\text { Has the potential for continuous improvement over } \\
\text { project stages } \\
\text { - Commitment from early commercial input from } \\
\text { private sector partner } \\
\text { - Creates clear roles and responsibilities, with less } \\
\text { conflicts of interest } \\
\text { Incremental partnership }\end{array}$ & $\begin{array}{l}\text { - Should the appointment of the strategic partner } \\
\text { occur before there is any fixed price tender for } \\
\text { works provision there may be less certainty about } \\
\text { their capacity to commission the appropriate } \\
\text { services } \\
\text { Piecemeal approach may militate against an } \\
\text { integrated supply-chain }\end{array}$ \\
\hline $\begin{array}{l}\text { - Can help to lower procurement costs } \\
\text { - } \quad \text { Arrangement gives high flexibility to meet changing } \\
\text { requirements } \\
\text { - Does not require a long-term contractual } \\
\text { relationship, although can be formed gradually } \\
\text { - Competitive pressures are maintained } \\
\text { Alliancing }\end{array}$ & - Major risks are held by the public sector \\
\hline $\begin{array}{l}\text { - There is a shared responsibility for ensuring that the } \\
\text { design is appropriate } \\
\text { - Allows flexibility to modify design and enables on- } \\
\text { going changes to be incorporated during } \\
\text { construction } \\
\text { - Incentives are given to both parties to complete the } \\
\text { project on time and on budget under the gain / pain } \\
\text { sharing philosophy } \\
\text { - An environment of 'no blame' eliminates the cost of } \\
\text { disputes }\end{array}$ & $\begin{array}{l}\text { - } \quad \text { Both parties must be genuinely committed to } \\
\text { openness and collaboration } \\
\text { - } \quad \text { Requires on-going involvement of appropriately } \\
\text { senior staff with public authority to resolve issues } \\
\text { - } \quad \text { Costs of establishing and maintaining alliance can } \\
\text { be considerable } \\
\text { - The approach has had only limited applications in } \\
\text { the public sector } \\
\text { - Only one design is developed } \\
\text { - } \quad \text { Less likelihood of achieving an innovative design } \\
\text { - } \quad \text { That maximises operational benefits } \\
\text { - } \quad \text { Public sector is left with overall design and 'fit for } \\
\text { purpose' risk }\end{array}$ \\
\hline
\end{tabular}

Source: Adapted from Deloitte Research (2006) and Ernst \& Young Project Finance Advisory. 


\section{MoDEL project}

This applies in similar circumstances to the LIFT/LEP model, but is especially designed for situations where the work is heterogeneous. MoDEL involves the consolidation of seven UK Ministry of Defence (MoD) sites to a single location in London. The approach taken has been to appoint a Prime Plus Contractor who assumes the principal risk on project delivery. All elements of the work are subject to open competition and the contractor competes for the initial specified works via a Fixed Price contract. All unspecified works are then competitively procured by the Prime Plus Contractor. The contractor primarily is paid through net disposal receipts from surplus property and is responsible for ensuring that timescales and quality standards are met, with rewards and penalties.

Sales proceeds are used to pay debt, direct project costs, and the contractor's management fee for delivering the project. Any excess is shared by the MoD and the contractor according to a profit-sharing mechanism. This formula ensures that there are strong incentives for keeping costs down. Facilities are thus rationalised and upgraded within a single contractual framework, with a partner who can take significant risks on behalf of the public sector. The project reached financial conclusion in summer 2006.

\section{Incremental partnership}

Here the government enters into a framework agreement with a private sector entity to procure the necessary infrastructure and services on behalf of the public sector. As its requirements become clearer, the government agency can 'call off' individual projects without any long-term commitment. The private sector partner competitively procures the services and infrastructure from subcontractors using its procurement expertise to negotiate the best deals. It also has overall responsibility for service levels against clear performance measures. Nevertheless, the authority is not bound to use the private sector partner, and retains the right to use alternative providers in which case the contracts and licences would revert to the public body. This avoids large-scale contracts that are difficult to reverse and require a long-term commitment from both parties. Such an incremental partnership approach was used in 2002 by Greenwich Council, London for its ICT facilities and services with Deloitte acting as 'service integrator' under the five year arrangement (Deloitte Research, 2006).

\section{Alliancing}

Under an alliance contract the public sector shares all the risks with the contractor in a relationship which encourages a 'no blame', 'solutions' based culture. The contract is based on an open book approach in which the contractor is generally paid for direct costs, with allowances for corporate overheads and a normal profit margin. A target cost for the works is established. Delivery of the project at a cost lower than the target amount will result in a sharing of the benefits, just as cost overruns will also be shared. Suitable for complex projects with considerable uncertainties and scope for design innovation, it presupposes that the public sector is an experienced manager of infrastructure projects and is able to retain 
all significant project risks. The intellectual origins of the collaborative framework lie in the 'partnering' agreements that emerged in the mid-1990s (Crowley and Karim, 1995; Hellard, 1995; Wilson, Songer and Diekmann, 1995), while cost-plus contracts have long been used in defence applications. The National Museum in Canberra was constructed under such an alliance approach.

\section{Conclusion}

In this article we have argued that PPPs are a way of introducing very different incentives into the procurement process. The theory of PPPs suggests that incentives to productive efficiencies can be introduced into infrastructure procurement by vesting control rights with the private sector, bundling into one contract the design, construction, operation and maintenance of the facility, and by transferring the risk of cost and time overruns to the private partner. To these arguments we would add, at a practical level, the disciplines injected by the participation of private capital that is genuinely 'at risk' and that is not artificially low and divorced from project risk. Evidence has been presented that the private sector does appear to respond to these signals.

Nonetheless, PPPs are not without difficulties. They are too complex, and costly, for many small projects. In some cases, they may be beyond the capacity of the public sector agency to implement and manage. For other projects the tight specification of the outputs required may be difficult to detail for an extended period. Recognition of these problems has seen the development of new hybrid PPPs, embodying different degrees of partnership, with the aim of reducing procurement costs and generating flexibility for evolving infrastructure needs, while retaining clear lines of responsibility and the proper motivation for the parties involved. The upshot of this blurring of conventional procurement and traditional PPP structures is a continuum of delivery models available to accommodate different risk preferences and infrastructure service needs.

\section{References}

Arthur Andersen (2000), Value for Money Drivers in the Private Finance Initiative, Arthur Andersen and Enterprise LSE, London.

Blanc-Brude, F., H. Goldsmith and T. Valila (2006), 'Ex-Ante Construction Costs in the European Road Sector: A Comparison of Public-Private Partnerships and Traditional Public Procurement', European and Financial Report 2006/01, European Investment Bank.

Brown, C. (2005), 'Financing Transport Infrastructure: For Whom the Road Tolls, Australian Economic Review 38 (4):431-8.

Clarke, H. and A. Hawkins (2006), 'Economic Framework for Melbourne Traffic Planning', Agenda 13 (1):63-80.

Cox, J. (2005), 'Caught on the road to nowhere', The Australian 28 November: 8.

Crowley, L. and M. Karim. (1995), 'Conceptual Model of Partnering,' Journal of Management in Engineering Sept/Oct:33-39. 
Deloitte Research (2006), Building flexibility: New Delivery Models for Public Ifrastructure Projects, Deloitte \& Touche LLP, London.

Ernst \& Young (2006), 'PPPs in Education', October, Project Finance Advisory, Australia.

Fitzgerald, P. (2004), Review of Partnerships Victoria Provided Infrastructure, Review of Partnerships Victoria, Melbourne.

Flyvbjerg, B., N. Bruzelius and W. Rothengatter (2003), Megaprojects and risk: An Anatomy of Ambition, Cambridge University Press, Cambridge.

Flyvbjerg, B., M. Holm and S. Buhl (2002), 'Underestimating Costs in Public Works Projects - Error or Lie?', Journal of the American Planning Association 68(3):279-295.

Flyvbjerg, B., M. Holm and S. Buhl (2005), 'How (In)accurate Are Demand Forecasts in Public Works Projects?', Journal of the American Planning Association 71(2):131-146.

Goldstone, D. (2001), 'Output-Based Education', Public Policy for the Private Sector, The World Bank Group Private Sector and Infrastructure Network, Note Number 233, May.

Grimsey, D. and M. Lewis (2004a), 'Discount Debates: Rates, Risk, Uncertainty and Value for Money in PPPs', Public Infrastructure Bulletin 3(March):4-7.

Grimsey, D. and M. Lewis (2004b), 'The Governance of Contractual Relationships in Public Private Partnerships, Journal of Corporate Citizenship 15(Autumn):91-109.

Grimsey, D. and M. Lewis (2004c), Public Private Partnerships: The Worldwide Revolution in Infrastructure Provision and Project Finance, Edward Elgar, Cheltenham.

Grimsey, D. and M. Lewis (eds) (2005a), The Economics of Public Private Partnerships, Edward Elgar, Cheltenham.

Grimsey, D. and M. Lewis (2005b), 'Are Public Private Partnerships Value for Money? Evaluating Alternative Approaches and Comparing Academic and Practitioner Views', Accounting Forum 4(29 December):345-78.

Grossman, S. and O. Hart (1986), 'The Costs and Benefits of Ownership: A Theory of Vertical and Lateral Integration', The Journal of Political Economy 94(4):691-719.

Grout, P. (1997), 'The Economics of the Private Finance Initiative', Oxford Review of Economic Policy 13(4):53-66.

Grout, P. (2003), 'Public and Private Sector Discount Rates in Public-Private Partnerships, Economic Journal 113(486): C62-C68.

Grout, P. (2005), 'Value-for-Money Measurement in Public-Private Partnerships, EIB Papers 10(2):32-56.

Harris, A. (1998), 'Credulity and Credibility in Infrastructure Funding', ACT Department of Urban Services Summer Seminar Series, Financing Urban Infrastructure and Services, University of Canberra, 6 March, www.audit.nsw.gov/au/publicvations/speeches/ag_ speech/1998/uc6398.htm, (accessed 30 April).

Harris, A. (2006), 'Edited Transcript of Four Corners Interview', www.abc.net.au/4corners/content/2006/s1573798.htm, accessed April 27, 2007. 
Hart, O. (2003), 'Incomplete Contracts and Public Ownership: Remarks, and an Application to Public-Private Partnerships, Economic Journa/113(486): C69-C76.

Hart, O. and J. Moore (1990), 'Property Rights and the Theory of the Firm', Journal of Political Economy 98:1119-1158.

Hellard, R. (1995), Project Partnering Principle and Practice, Thomas Telford, London.

HM Treasury (2003a), The Green Book - Appraisal and Evaluation in Central Government, TSO, London.

HM Treasury (2003b), PFI: Meeting the Investment Challenge, HMSO, Norwich.

Hodgson, G. (1995), 'Design and Build - Effects of Contractor Design on Highway Schemes', Proc. Civil Engineers 108(May):64-76.

House of Commons Committee of Public Accounts (2006a), The Refinancing of the Norfolk and Norwich Hospital, Thirty-fifth report of session 2005-06, May, London.

House of Commons Committee of Public Accounts (2006b), NHS Local Improvement Finance Trusts (LIFT), Forty-seventh report of session 2005-06, July, London.

Leahy, P. (2005), 'Lessons from the Private Finance Initiative in the United Kingdom', $E / B$ Papers, 10(2):58-71.

Mackie, P. and J. Preston (1998), 'Twenty-One Sources of Error and Bias in Transport Project Appraisal', Transport Policy 5:1-7.

Macniel, I. (1974), 'The Many Futures of Contracts', Southern California Law Review 47:691-816.

Mott MacDonald (2002), Review of Large Public Procurement in the UK, HM Treasury, London.

National Audit Office (1998), The Private Finance Initiative: The First Four, Design, Build, Finance and Operate Roads Contracts, HC 476, Parliamentary Session 1997-98, HMSO, London.

National Audit Office (2001), Managing the Relationship to Secure a Successful Partnership in PFI Projects, HC 375 Session 2001/2002, HMSO, London.

National Audit Office (2003), PFI: Construction Performance, Report by the Comptroller and Auditor General, HMSO, London.

National Audit Office (2005), PFI: Construction Performance, Report by the Comptroller and Auditor General, HMSO, London.

Parker, D. and K. Hartley (2003), 'Transaction Costs, Relational Contracting and Public Private Partnerships: A Case Study of UK Defence', Journal of Purchasing and Supply Management 9(3):97-108.

PricewaterhouseCoopers (2002), Study into Rates of Return Bid on PFI Projects, OGC, London.

Sachs, T., C. Elbing, R. Tiong and H. Alfen (2005), 'Efficient Assessment of Value for Money (VFM) for Selecting Effective Public Private Partnership (PPP) Solutions - A Comparative 
Study of VFM Assessment for PPPs in Singapore and Germany', CACS, School for Civil and Environmental Engineering, Nanyang Technological University, Singapore.

Sendt, R. (2006), 'Public Private Partnerships', CEDA Lunch, 10 April, The Audit Office of New South Wales.

Stone, T. (2006), 'PFI - Is There a Better Way?' KPMG Global Infrastructure and Projects Group, London.

Thomson, C. (2005), 'Public-Private Partnerships: Prerequisites for Prime Performance,' EIB Papers 10(2):112-129.

Thornton, E. (2007), 'Roads to Riches', Business Week 7 May:50-7.

Wilson, R., A. Songer and J. Diekmann (1995), Partnering: More than a Workshop, a Catalyst for Change', Journal of Management in Engineering Sept/Oct:40-45.

The authors are grateful to two anonymous referees and the Editor for helpful comments. 